\title{
Hyperuricemia and tumor lysis syndrome in children with non-Hodgkin's lymphoma and acute lymphoblastic leukemia
}

\author{
Non-Hodgkin lenfoma ve akut lenfoblastik lösemili çocuklarda \\ hiperürisemi ve tümör lizis sendromu
}

\author{
Betül Sevinir1, Metin Demirkaya ${ }^{1}$, Birol Baytan², Adalet Meral Güneş² \\ ${ }^{1}$ Department of Pediatric Oncology, Medical Faculty, Uludağ University, Bursa, Turkey \\ 2Department of Pediatric Hematology, Medical Faculty, Uludağ University, Bursa, Turkey
}

\begin{abstract}
Objective: This study aimed to examine the incidence, clinical characteristics, and outcome of hyperuricemia and tumor lysis syndrome (TLS) in children with non-Hodgkin's lymphoma (NHL) and acute lymphoblastic leukemia (ALL).

Materials and Methods: This retrospective study included data from 327 patients (113 NHL and 214 ALL). Results: Hyperuricemia occurred in $26.5 \%$ and $12.6 \%$ of the patients with NHL and ALL, respectively. The corresponding figures for TLS were $15.9 \%$ and $0.47 \%(p=0.001)$. All hyperuricemic NHL patients had advanced disease and renal involvement was present in 53\%. All hyperuricemic ALL patients had a leukocyte count $>50,000 \mathrm{~mm}^{3}$ at the time of diagnosis. Among the hyperuricemic NHL and ALL patients, $96.6 \%$ and $66.6 \%$ had LDH $\geq 500 \mathrm{UI} / \mathrm{L}$, respectively. Treatment consisted of hydration and allopurinol; none of the patients received urate oxidase. Among the patients that developed TLS, $26.3 \%$ had laboratory TLS, $42.1 \%$ had grade I or II TLS, and $31.6 \%$ had grade III or IV TLS. Uric acid levels returned to normal after a mean period of 3.5 \pm 2.5 and $3.05 \pm 0.8 \mathrm{~d}$ in NHL and ALL groups, respectively. In all, $7 \%$ of the patients with hyperuricemia required hemodialysis. None of the patients died.

Conclusion: In this series the factors associated with a high-risk for TLS were renal involvement in NHL and high leucocyte count in ALL. Management with allopurinol and hydration was effective in this group of patients with high tumor burden. (Turk J Hematol 2011; 28: 52-9)

Key words: Non-Hodgkin's lymphoma, leukemia, tumor lysis syndrome, hyperuricemia, children
\end{abstract}

Received: January 28, 2010

Accepted: April 30, 2010

\section{Özet}

Amaç: Çalışmanın amacı NHL ve ALL'li çocuklarda hiperürisemi ve TLS sıklığını, klinik özellikleri ve sonuçlarını tanımlamaktır. 


\begin{abstract}
Yöntem ve Gereçler: Bu retrospektif çalışmada 113 NHL ve 214 ALL'li toplam 327 hastanın verileri değerlendirildi.

Bulgular: NHL olgularının \%26.5'inde, ALL olgularının \%12.6'sında hiperürisemi görüldü. TLS insidansı NHL ve ALL gruplarında \%15.9 ve \%0.47 bulundu $(p=0.001)$. Hiperürisemi görülen NHL olgularının tümü ileri evrede olup, $\% 53$ 'ünde renal tutulum vardı. Tüm hiperürisemili ALL olgularında tanıda lökosit sayımı 50.000/mm ${ }^{3}$ 'den yüksekti. Hiperürisemik NHL grubunun \%96.6'sında, ALL grubunun \%66.6'sında LDH $\geq 500$ UI/L idi. Tedavide hidrasyon ve allopürinol uygulandı, ürat oksidaz verilen hasta olmad. TLS gelişen olguların \%26.3'ünde laboratuvar TLS, \%42,1'inde grade I ve grade II TLS, \%31.6'sında grade III ve IV TLS saptandi. Ürik asit düzeyleri NHL ve ALL hastalarında ortalama $3.5 \pm 2.5$ ve $3.05 \pm 0.8$ günde normale döndü. Hiperürisemili hastaların $\% 7$ 'sinde hemodiyaliz gerekti. Mortalite olmad.

Sonuç: Bu seride en yüksek TLS riski renal tutulumu olan NHL olgularında saptandı. Allopürinol ve hidrasyonun tümör yükü yüksek olan bu grupta etkili olduğu gözlendi. (Turk J Hematol 2011; 28: 52-9)

Anahtar kelimeler: Non-Hodgkin lenfoma, lösemi, tümör lizis sendromu, hiperürisemi, çocuklar

\section{Introduction}

Tumor lysis syndrome (TLS) is a complication of cancers that are highly sensitive to cytotoxic agents, and have a high tumor burden and proliferation rate. Acute renal injury may ensue due to hyperuricemia, hyperkalemia, hyperphosphatemia, and hypocalcemia. Uric acid is an important mediator of renal injury in TLS, and hyperuricemia is one the first signs of TLS [1,2]. Nonetheless, not all patients with hyperuricemia develop other signs of TLS. Although TLS may also occur in solid tumors, patients with nonHodgkin's lymphoma (NHL) and acute leukemia represent the majority of cases [1-3].

In Turkey acute leukemias and lymphomas are the most frequent childhood cancers [4,5]. NHL and acute lymphoblastic leukemia (ALL) are frequently associated with a number of adverse metabolic consequences due to high cell turnover and a high response rate to cytotoxic agents. Most children in Turkey with NHL are diagnosed at an advanced stage $[4,6]$. As such, metabolic disturbances that require urgent treatment are frequently observed. Among these, hyperuricemia has recently emerged as an important complication associated with the use of newer therapeutic agents. Allopurinol, a xanthine oxidase inhibitor, has traditionally been used to treat hyperuricemia; it blocks the production of uric acid from xanthine and hypoxanthine without affecting the breakdown of already formed uric acid, and at the same time prevents new production.

Alkalinization of urine may increase the excretion of uric acid via urine [1,2]. In recent years, recombinant urate oxidase has been introduced, which is an enzyme that exists in many mammalians, but not humans. This enzyme allows urinary excretion of uric acid by converting it to allantoin, which is $5-10$-fold more soluble in water than uric acid; however, urate oxidase causes hemolysis in patients with glucose-6-phosphate dehydrogenase (G6PD) enzyme deficiency and is expensive. Hyperuricemia and acute TLS may lead to adverse consequences, including renal insufficiency or sudden death. TLS has been graded on the basis of laboratory and clinical features, with the Cairo and Bishop TLS classification systems being the most recent [7]. Additionally, guidelines for preventing morbidity and mortality have been issued, despite the lack of a consensus.

In Turkey the incidence of hyperuricemia in children with NHL and ALL has not been specifically addressed and, therefore, the present study aimed to determine the frequency, grade, clinical course, and outcome of hyperuricemia in children with NHL and ALL. Moreover, the efficacy of the protocol used at our hospital for the prevention and treatment of hyperuricemia and TLS was re-assessed.

\section{Material and Methods}

\section{Patients}

The medical records of children with NHL and ALL that were treated at our hospital between January 1997 and December 2007 were retrospectively evaluated. Age, gender, histopathological group, disease stage, and the presence of renal involvement, and serum lactate dehydrogenase (LDH), urea, uric acid, creatinine, calcium, phosphorus, and electrolyte levels were assessed in NHL 
patients. In the patients with ALL, age, gender, leukocyte count at the time of diagnosis, risk group status, and the presence of renal involvement, and serum LDH, urea, uric acid, creatinine, calcium, phosphorus, and electrolyte levels were assessed.

Spontaneous or post-chemotherapy elevation of uric acid levels and signs of acute TLS were recorded, as were the response to the routine hyperuricemia management protocol, number of days required for normalization of uric acid levels, number of patients that required hemodialysis, and mortality data. The Local Ethical Committee of Uludağ University Medical Faculty approved this retrospective study (Approval number: 2009-11/80).

\section{Chemotherapy protocol}

The NHL BFM-95 and ALL BFM-95 protocols were used for the treatment of NHL and ALL patients, respectively.

Criteria for hyperuricemia and acute tumor lysis syndrome

Serum uric acid levels above normal were considered hyperuricemia (normal range: $2.2-7.2 \mathrm{mg}$ / $\mathrm{dL}$ ). TLS was defined on the basis of Cairo and Bishop criteria [7]. Accordingly, laboratory TLS (L TLS) criteria were as follows: serum uric acid $\geq 8 \mathrm{mg}$ /
$\mathrm{dL}(476 \mu \mathrm{mol} / \mathrm{L})$, serum potassium $\geq 6 \mathrm{mEqL}^{-1}(6$ $\mathrm{mmol} / \mathrm{L})$, serum phosphorus $>6.5 \mathrm{mg} / \mathrm{dL}(2.1$ $\mathrm{mmol} / \mathrm{L})$, and serum calcium $<7 \mathrm{mg} / \mathrm{dL}$ (1.75 $\mathrm{mmol} / \mathrm{L}$ ), or a $25 \%$ increase from baseline in the first 3 parameters, or a $25 \%$ decrease from baseline in serum calcium. Fulfillment of at least 2 laboratory criteria from $3 \mathrm{~d}$ prior to cytotoxic treatment to $7 \mathrm{~d}$ after was diagnostic for LTLS. Clinical TLS (CTLS) was defined on the basis of renal, cardiac, and neurological changes (Table 1). Data for hyperuricemic patients were classified according to LTLS and CTLS criteria.

\section{Routine management protocol for hyperuricemia}

Routine prophylaxis and treatment were given to all the NHL and ALL patients. As such, all patients with uric acid levels at the upper limit of normal or those with a high risk of acute TLS received intravenous hydration and oral allopurinol. Hydration was given for $24 \mathrm{~h}$ be be fore chemotherapy and the total daily dose ranged between 2500 and $3000 \mathrm{~mL} / \mathrm{m}^{-2}$. The urine density and $\mathrm{pH}$ range were set at 1010 and 6.7-7, respectively. Allopurinol - 300 and 200 $\mathrm{mg} \cdot \mathrm{m}^{-2} \cdot \mathrm{d}^{-1}$ p.o. - was given in 3 divided doses to the NHL and ALL patients, respectively. None of the patients received urate oxidase.

Table 1. Cairo-Bishop TLS grading system [7]

\begin{tabular}{|c|c|c|c|c|}
\hline & LTLS & Creatinine & $\begin{array}{c}\text { Cardiac } \\
\text { arrhythmia }\end{array}$ & Seizure \\
\hline Grade 0 & - & $<1.5 \times \mathrm{ULN}$ & None & None \\
\hline Grade I & + & $1.5 \times \mathrm{ULN}$ & $\begin{array}{l}\text { Intervention } \\
\text { not indicated }\end{array}$ & - \\
\hline Grade II & + & $1.5-3 \times \mathrm{ULN}$ & $\begin{array}{c}\text { Non-urgent medical } \\
\text { intervention }\end{array}$ & $\begin{array}{l}\text { Brief, generalized seizure(s) } \\
\text { controlled with anticonvulsants, } \\
\text { or infrequent focal motor seizures } \\
\text { not interfering with daily activity }\end{array}$ \\
\hline Grade III & + & $3-6 \times \mathrm{ULN}$ & $\begin{array}{l}\text { Symptomatic and } \\
\text { incomplete }\end{array}$ & $\begin{array}{c}\text { Seizures in which consciousness is } \\
\text { altered, controlled medically or poorly } \\
\text { controlled, with breakthrough generalized } \\
\text { control, with device seizures despite } \\
\text { medical intervention }\end{array}$ \\
\hline Grade IV & + & $>6 \approx \mathrm{ULN}$ & $\begin{array}{l}\text { Life threatening } \\
\text { (e.g. arrhythmia associated } \\
\text { with congestive heart, } \\
\text { failure, hypotension, } \\
\text { syncope, shock) }\end{array}$ & $\begin{array}{l}\text { Seizure of any kind that is } \\
\text { prolonged, repetitive, or difficult } \\
\text { to control (e.g. status epilepticus, } \\
\text { intractable epilepsy) }\end{array}$ \\
\hline Grade V & + & Death & Death & Death \\
\hline
\end{tabular}


Table 2. Patient characteristics

\begin{tabular}{|c|c|c|c|}
\hline & NHL & ALL & $\mathbf{P}$ \\
\hline Number of patients & 113 & 214 & - \\
\hline Median age [years] (range) & $6.5(0.9-17.3)$ & $5.5(1.16-17.5)$ & 0.8 \\
\hline Gender (n, male/female) & $90 / 23$ & $131 / 83$ & - \\
\hline Stage III, IV (n, \%) & $110(97.3)$ & - & - \\
\hline High WBC* (n, \%) & - & $28(13)$ & - \\
\hline $\mathrm{LDH} \dagger(\mathrm{UI} / \mathrm{L})$ & $895 \pm 1246$ & $372 \pm 213$ & 0.02 \\
\hline High LDH level** (n, \%) & $64(56)$ & $26(12)$ & \\
\hline Uric Acid $\dagger(\mathrm{mg} / \mathrm{dL})$ & $5.79 \pm 4.13$ & $5.81 \pm 2.37$ & 0.2 \\
\hline Urea $\dagger(\mathrm{mg} / \mathrm{dL})$ & $30.5 \pm 35.8$ & $26.6 \pm 12.5$ & 0.3 \\
\hline Creatinine $\dagger(\mathrm{mg} / \mathrm{dL})$ & $0.74 \pm 0.9$ & $0.53 \pm 0.11$ & 0.11 \\
\hline Renal involvement (n, \%) & $32(28.2)$ & - & \\
\hline Hyperuricemia (n, \%) & $30(26.5)$ & $27(12.6)$ & 0.05 \\
\hline ATLS (n, \%) & $18(15.9)$ & $1(0.47)$ & 0.001 \\
\hline
\end{tabular}

\section{Statistical method}

Age, LDH concentration, biochemical parameters, and leukocyte counts are presented as mean \pm standard deviation (SD). Gender, hyperuricemia, hyperleukocytosis, and the frequency of TLS are presented as percentages. The NHL and ALL groups were compared using the t-test and chisquare test to determine the significance of the differences between means, and between the subgroups with or without uricemia in each group. The findings in the NHL and ALL patients with and without hyperuricemia were statistically compared using the t-test or chi-square test. Statistical comparisons were performed using SPSS v.10.0.

\section{Results}

Data obtained from a total of 327 newly diagnosed patients with NHL $(n=113)$ and ALL $(n=214)$ between December 1997 and January 2007 were examined. Table 2 shows the epidemiological and clinical characteristics of the patients. Mean age at the time of diagnosis was $6.5 \pm 5.2$ years (range: 0.9 17.3 years) and 6.1 \pm 3.9 years (range: 1.16-17.5 years) in the NHL and ALL groups, respectively $(\mathrm{P}=0.8)$.

Among the patients with NHL, 68\% $(n=77)$ had B-cell, 28\% $(n=31)$ had lymphoblastic, and 4\% $(n=5)$ had anaplastic large cell lymphoma. According to the St. Jude staging system, 2.7\% $(n=3), 77 \%(n=87)$, and $20.3 \%(n=23)$ had stage II, III, and III disease, respectively. Mean LDH level was $895 \pm 1246 \mathrm{IU} / \mathrm{L}$, with $56 \%$ of the patients having an LDH level $>500 \mathrm{IU} / \mathrm{L}$. Among the ALL patients, $65 \%$ $(n=139), 16.8 \%(n=36)$, and $18.2 \%(n=39)$ were in the standard-, medium-, and high-risk categories, respectively. Mean LDH level was $372 \pm 213 \mathrm{IU} / \mathrm{L}$, and $12 \%(26 / 214)$ had an LDH level $>500$ IU/L. In all, 28 of the children with leukemia (13\%) had a leukocyte count $>50,000 \mathrm{~mm}^{3}$ (range: 50,000-192,000 $\mathrm{mm}^{3}$; mean: $82,985 \pm 39,029 \mathrm{~mm}^{3}$ ). Mean serum urea, creatinine, and uric acid levels did not differ significantly between the NHL and ALL patients (Table 2).

Serum uric acid levels were above the normal range, corresponding to hyperuricemia in 30 children (26.5\%) with NHL and 27 children (12.6\%) with $\operatorname{ALL}(p=0.05)$. TLS criteria were met by $15.9 \%(n=18)$ of the NHL patients and 1 (0.47\%) ALL patient $(\mathrm{p}=0.001)$. The majority of hyperuricemic NHL cases $(25 / 30,83 \%)$ presented at initial diagnosis, of which 5 (17\%) developed hyperuricemia following the first dose of chemotherapy; the corresponding figures for hyperuricemic ALL patients were 59\% (16/27) and $41 \%$ (11/27), respectively. A comparison of the characteristics of the hyperuricemic and normouricemic patients is shown in Table 3. All hyperuricemic NHL patients had stage III or IV disease, and their mean urea and creatinine concentrations were higher than those in the normouricemic cases $(p=0.001$ 
and $\mathrm{p}=0.001$, respectively). In $96.6 \%$ of the hyperuricemic NHL patients LDH was $>500 \mathrm{UI} / \mathrm{L}$ (mean concentration: $1286 \pm 1378 \mathrm{UI} / \mathrm{L})$. LDH levels in the hyperuricemic cases were significantly higher than those in the normouricemic cases $(p=0.001)$. Of the hyperuricemic NHL patients, 53\% had renal involvement, as compared to $19 \%$ of the non-hyperuricemic NHL patients $(p=0.001)$ (Table 3$)$.

Among the hyperuricemic ALL patients, 59\% and $41 \%$ were in the medium- and high-risk categories, respectively. Mean LDH was $967 \pm 798 \mathrm{UI} / \mathrm{L}$, with $66.6 \%$ of the cases (18/27) having an LDH level $>500$ UI/L. All hyperuricemic ALL cases had an elevated white cell count, versus $1(0.5 \%)$ patient in the nonhyperuricemic ALL group $(p=0.0001)$. No patient had renal involvement. LDH levels were not significantly different between the NHL and ALL patients $(p=0.29)$, nor were creatinine or urea $(p=0.15$ and $\mathrm{p}=0.8$, respectively). Mean serum uric acid level in the hyperuricemic NHL and ALL patients was $13.29 \pm 5.92 \mathrm{mg} / \mathrm{dL}$ and $8.82 \pm 1.4 \mathrm{mg} / \mathrm{dL}$, respectively $(\mathrm{p}=0.0001)$. The maximum uric acid concentration in these 2 groups was $30.4 \mathrm{mg} / \mathrm{dL}$ and $13 \mathrm{mg} / \mathrm{dL}$, respectively.

Table 4 shows the TLS grading. None of the patient with TLS developed arrhythmia or seizure. Among the hyperuricemic NHL patients, renal involvement was observed in $77 \%$ and $25 \%$ of the cases that did and did not develop TLS, respectively (Fisher's exact test, $\mathrm{p}=0.008$ ). Including the $1 \mathrm{ALL}$ patient with TLS, in all 5 patients with TLS (26.3\%) LTLS was diagnosed without clinical signs. Grade I, II, III, and IV CTLS was observed in 15.8\%, 26.3\%, $26.3 \%$, and $5.3 \%$ of the patients, respectively. Routine treatment for hyperuricemia resulted in normalization of the uric acid level within 1-10 d. On average, normouricemia was achieved within $3.57 \pm 2.1$ and $3.07 \pm 0.8 \mathrm{~d}$ in NHL and ALL patients, respectively $(\mathrm{P}=0.22)$ (Figure 1). All hyperuricemic ALL patients had their serum uric acid level normalized following the routine treatment protocol for hyperuricemia. Of the 30 NHL patients, 26 had their uric acid and other biochemical parameters normalized, while among the 4 patients that developed TLS (21\%), 3 cases with grade III disease and 1 case with grade IV disease required hemodialysis due to refractory hyperphosphatemia and oligoanuria. Patients that required hemodialysis represented $7 \%$ $(n=4 / 57)$ of the patient population with hyperurice-

Table 4. Cairo-Bishop grading results in the TLS cases

\begin{tabular}{lc}
\hline $\begin{array}{l}\text { Grade } \\
(\mathbf{n}=19)\end{array}$ & n (\%) \\
\hline LTLS & $5(26.3)$ \\
\hline Grade I & $3(15.8)$ \\
\hline Grade II & $5(26.3)$ \\
\hline Grade III & $5(26.3)$ \\
\hline Grade IV & $1(5.3)$ \\
\hline Grade V & - \\
\hline
\end{tabular}

LTLS: Laboratory tumor lysis syndrome

Table 3. Characteristics of the hyperuricemic and normouricemic patients

\begin{tabular}{|c|c|c|c|c|c|c|}
\hline & $\begin{array}{c}\text { NHL } \\
\text { hyper- } \\
\text { uricemic } \\
(n=30)\end{array}$ & $\begin{array}{c}\text { NHL } \\
\text { non-hyper- } \\
\text { uricemic } \\
(n=83)\end{array}$ & $\mathbf{P}$ & $\begin{array}{c}\text { ALL } \\
\text { hyper- } \\
\text { uricemic } \\
(n=27)\end{array}$ & $\begin{array}{c}\text { ALL } \\
\text { non-hyper- } \\
\text { uricemic } \\
(n=187)\end{array}$ & $\mathbf{P}$ \\
\hline $\mathrm{LDH}^{*}(\mathrm{UI} / \mathrm{L})$ & $1286 \pm 1378$ & $753 \pm 1170$ & 0.04 & $967 \pm 798$ & $286 \pm 194$ & 0.01 \\
\hline High $\mathrm{LDH}^{* *}(\mathrm{n}, \%)$ & $29(96.6)$ & $35(42.2)$ & 0.001 & $18(66.6)$ & $11(5.9)$ & 0.001 \\
\hline Uric Acid* (mg/dL) & 13.295 .92 & $3.76 \pm 1.33$ & 0.0001 & $8.82 \pm 1.4$ & $5.6 \pm 4.32$ & 0.02 \\
\hline Urea* (mg/dL) & $54.73 \pm 62$ & $21.54 \pm 6.24$ & 0.001 & $51.71 \pm 12$ & $20.6 \pm 2.20$ & 0.001 \\
\hline Creatinine* (mg/dL) & $1.22 \pm 1.78$ & $0.56 \pm 0.15$ & 0.001 & $0.72 \pm 0.090 .5 \pm 0.01$ & 0.05 & \\
\hline $\begin{array}{l}\text { Renal involvement } \\
(\mathrm{n}, \%)\end{array}$ & $16(53)$ & $16(19)$ & & 0.001 & - & - \\
\hline High WBC $†(n, \%)$ & - & & - & $27(100)$ & $1(0.5)$ & 0.0001 \\
\hline TLS (n, \%) & & $18(60)$ & & $-1(3.7)$ & - & \\
\hline $\begin{array}{l}\text { Recovery time* } \\
\text { (days) }\end{array}$ & $3.57 \pm 2.1$ & - & $3.07 \pm 0.8$ & - & 0.22 & \\
\hline
\end{tabular}

*Mean \pm SD, ${ }^{* *}$ High LDH: $\geq 500 \mathrm{IU} / \mathrm{L}, \dagger$ High WBC: $\geq 50,000 \mathrm{~mm}^{-3}$. 


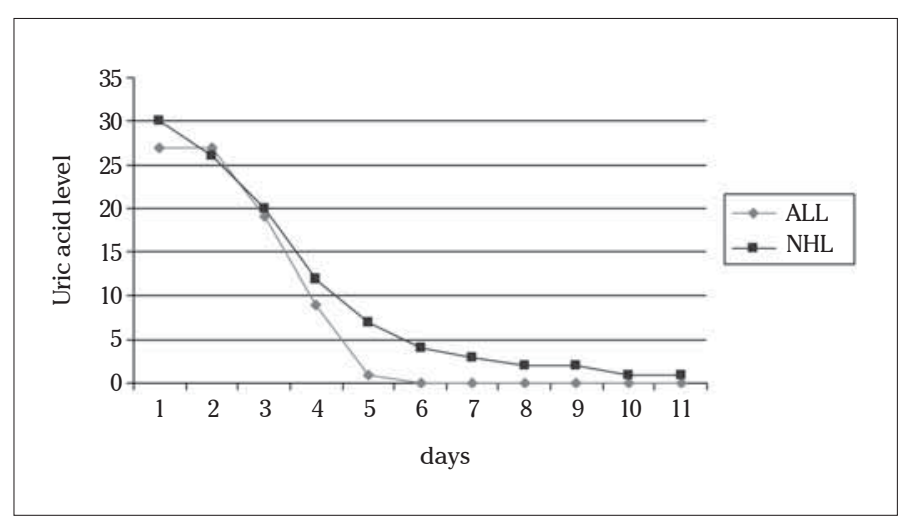

Figure 1. Comparison of serum uric acid level during treatment in NHL and ALL patients

mia. In the presented patient series no deaths were recorded during hyperuricemia or TLS.

\section{Discussion}

Hyperuricemia, which is the most common pediatric metabolic emergency, is a sign of TLS that occurs in high grade NHL, B-cell ALL, and acute myelocytic leukemia patients [1,2,7]; however, it has also been reported in some solid tumors, such as neuroblastomas and germ cell tumors. It can occur spontaneously or due to tumor lysis caused by a number of therapeutic modalities, including conventional cytotoxic chemotherapy, anti-CD20 monoclonal antibodies, and radiotherapy. It can also be triggered by administration of a single dose of steroid $[1,2,6,8]$.

The reported frequency of hyperuricemia and TLS is primarily based on single-center studies, and varies between $5 \%$ and $42 \%$. Patients with B-cell lymphoma or Burkitt's lymphoma were reported to experience this condition twice as frequently as patients with T-cell lymphoma [9-12]. In multi-center NHL trials of the BFM-90 and 95 protocols, $4.4 \%$ of the total study population (78 out of 1791) experienced TLS, which occurred in $8.4 \%$ of the patients in the Burkitt's lymphoma and B-cell ALL subgroups, versus $1.9 \%$ in the T-lymphoblastic lymphoma subgroup [11]. Metabolic catabolism was reported in 34 of the 410 patients (8\%) with grade III and IV NHL, and B-cell ALL that were included in the LMB-89 protocol. Severe TLS was reported in 5\% of patients and $1.7 \%$ required hemodialysis. In that series high tumor burden prevailed and 14\% had renal involvement [13]. In a study from Turkey clinical signs and outcomes were reported for $97 \mathrm{NHL}$ patients, including 72 cases that received LMB-89 and 25 that received a modified LMT-89 protocol. Among these patients, $89.7 \%$ had stage III or IV disease, and 34 (35\%) had TLS and hyperuricemia. Severe TLS was reported in $16.5 \%$ of the patients, of which $26 \%$ required hemodialysis [14].

Among patients with B-cell NHL that received a modified NHL BFM protocol, the reported incidence of TLS was 14\% [15]. In the present study's sample $30(26.5 \%)$ of the 113 NHL patients had hyperuricemia and 18 (15.9\%) had TLS, which is consistent with previously published data, and can be explained on the basis of the similarities in the biological and clinical characteristics of the patients in Turkey. The high incidence of B-cell lymphomas and the transitional nature of Burkitt's lymphoma between the endemic and sporadic types result in a high number of advanced cases and increases the frequency of metabolic emergencies in Turkey $[16,17]$. This is similar to other reports from the same geographical location. For instance, TLS was reported in $22.5 \%$ of 59 patients with NHL, approximately $50 \%$ in the form of LTLS [18].

In patients with NHL and ALL tumor burden is associated with increased severity of hyperuricemia, while TLS or the need for hemodialysis is more likely to occur with renal involvement, which has been reported in 14\%-61\% of patients with TLS $[13,15,19]$. In the present study renal involvement occurred in $19 \%$ of the NHL patients and $53 \%$ of the hyperuricemic patients; this figure was $77 \%$ in the patients that developed TLS, as compared to $25 \%$ in those that did not $(\mathrm{p}=0.008)$. Renal involvement not only increases the risk of acute complications, but also has adverse consequences with regard to longterm prognosis [20]. None of the ALL patients in the present study had renal involvement. More severe hyperuricemia and a high incidence of TLS in the NHL group were probably associated with bulky disease accompanied by renal involvement.

Similar to risk stratification in lymphoma patients, cases with ALL and AML can be classified in terms of the risk of hyperuricemia. Hyperleukocytosis, B-cell ALL, bulky mediastinal masses, and high LDH levels are likely to be associated with increased risk of hyperuricemia in leukemic patients [1,10-13,21].

In the present study all the hyperuricemic ALL patients had high tumor burden and elevated leukocyte counts, and $66.6 \%$ had elevated LDH levels ( $\geq 500 \mathrm{UI} / \mathrm{L}$ ), which highlights the importance of 
tumor burden in ALL patients. To the best of our knowledge this is the first study from Turkey to compare the incidence of hyperuricemia and TLS in patients with $\mathrm{NHL}$ and ALL diagnosed at the same center. The present data show that there was a 2.1and 33-fold increase in hyperuricemia and TLS, respectively, in children with NHL. These findings suggest that pediatric NHL patients with advanced disease and renal involvement represent the primary risk group for TLS.

Of the 19 TLS cases reported here, $26.3 \%$ (n:5) met the criteria for LTLS and none had CTLS. Among the other 14 cases, $15.8 \%$ and $26.3 \%$ were classified as grade I and grade II, respectively. The rest had grade III (26.3\%) and grade IV (5.3\%) CTLS. Additionally, the severity of CTLS correlated with the requirement for hemodialysis. The prognostic significance of this novel classification is yet unknown and to clarify this issue clinical outcomes should be assessed in prospective studies.

Despite previous reports of mortality and high hemodialysis rates associated with allopurinol treatment in TLS, in the present study high-risk patients were treated with hydration, alkalinization, and allopurinol, and no mortality associated with TLS was recorded. Additionally, none of the patients received urate oxidase and $7 \%$ required hemodialysis.

Substitution of allopurinol with urate oxidase has been reported to decrease the incidence and severity of TLS $[22,23]$. The cost-effectiveness of urate oxidase is a subject of continuing research worldwide [24]. Urate oxidase is administered with varying doses and durations, depending on the level of risk. The major advantages of urate oxidase are rapid fall in serum uric acid level after a single dose and no prerequisite for urinary alkalinization; however, high acquisition cost and hemolysis in patients with G6PD enzyme deficiency are the major drawbacks limiting its use $[2,7,12,23]$. In the present study serum uric acid levels returned to normal in a mean $3.5 \mathrm{~d}$. We think that selective use of allopurinol is a rational approach in such cases when resources are limited.

\section{Conflict of interest statement}

None of the authors of this paper has a conflict of interest, including specific financial interests, relationships, and/or affiliations relevant to the subject matter or materials included.

\section{References}

1. Davidson MB, Thakkar S, Hix JK, Bhandankar ND, Wong A, Schreiber MJ. Pathophysiology, clinical consequences, and treatment of tumor lysis syndrome. Am J Med 2004; 116:546-54. [CrossR ef]

2. Hochberg J, Cairo MS. Tumor lysis syndrome: Current perspective. Haematologica 2008; 93:9-13. [CrossR ef]

3. Baeksgaard L, Sorensen JB. Acute tumor lysis syndrome in solid tumors- a case report and review of the literature. Cancer Chemother Pharmacol 2003;51:187-92.

4. Buyukpamukcu M. Non-Hodgkin's lymphomas. In: Voute T, Kalifa C, Barret A (Eds). Cancer in children. Fourth edition, Oxford, UK: Oxford University Press; 1998;119-36.

5. Kutluk T, Yesilipek MA. Turkish National Pediatric Cancer Registry 2002-2008 (Turkish Pediatric Oncology Group and Turkish Pediatric Hematology Society) Pediatr Blood Cancer 2009; 53:(abstract) pp25.

6. Yaris N, Mandiracioglu A, Buyukpamukcu M. Childhood cancer in developing countries. Pediatr Hematol Oncol 2004;21:237-53. [CrossR ef]

7. Cairo M, Bishop M. Tumour lysis syndrome: new therapeutic strategies and classification. $\mathrm{Br} \mathrm{J}$ Haematol 2004;127:3-11. [CrossR ef]

8. Duzova A, Cetin M, Gümrük F, Yetgin S. Acute tumour lysis syndrome following a single-dose corticosteroid in children with acute Iymphoblastic leukemia. Eur J Haematol 2001;66:404-7. [CrossR ef]

9. Eldar AH, Futerman B, Abrahami G, Attias D, Barak AB, Burstein Y, Dvir R, Gabriel H, Horovitz J, Kapelushnik J , Kaplinsky H, Miskin H, Sthoeger D, Toren A, Vilk-Revel S, Weintraub M, Yaniv I, Linn S, Arush MB. Burkitt lymphoma in children. The Israeli Experience. J Pediatr Hematol Oncol 2009;31:428-36. [CrossR ef]

10. Seidemann K, Meyer U, J ansen P, Yakisan E, Rieske K, Fuhrer M, Kremens B, Schrappe M, Reiter A. Impaired renal function and tumor lysis syndrome in pediatric patients with non-Hodgkin's lymphoma and B-ALL. Observations from the BFM-trials. Klin Padiatr 1998;210:279-84. [CrossR ef]

11. Wossmann W, Schrappe M, Meyer U, Zimmermann M, Reiter A. Incidence of tumor lysis syndrome in children with advanced stage Burkitt's lymphoma/leukemia before and after introduction of prophylactic use of urate oxidase.Ann Hematol 2003;82:160-5. [CrossR ef]

12. Coiffier B, Altman A, Pui CH, Younes A, Cairo MS. Guidelines for the management of pediatric and adult tumor lysis syndrome: An evidence -based review. J Clin Oncol 2008;26:2767-78. [CrossR ef]

13. Patte C, Sakiroglu C, Ansoborlo S, Baruchel A, Plouvier $\mathrm{E}$, Pacquement $\mathrm{H}$, Babin-Boilletot $\mathrm{A}$. Urate-oxidase in the prevention and treatment of metabolic complications in patients with B-cell lymphoma and leukemia, treated in the Société Française d'Oncologie Pédiatrique LMB89 protocol. Ann Oncol 2002;13:78995. [CrossR ef] 
14. Kutluk T, Varan A, Akyüz C, Buyukpamukcu M. Clinical characteristics and treatment results of LMB/LMT regimen in children with non-Hodgkin's lymphoma. Cancer Invest 2002;20:626-33. [CrossRef]

15. Karadeniz C, Oguz A, Citak EC, Uluoglu O, Okur V, Demirci S, Okur A, Aksakal N. Clinical characteristics and treatment results of pediatric B-cell non-Hodgkin lymphoma patients in a single center. Pediatr Hematol Oncol 2007;24:417-30. [CrossRef]

16. Kutluk T, Sarıalioğlu F, Göğüş S, Akyüz C, Büyükpamukçu M. Burkitt's lymphoma in Turkish children: A retrospective analysis of 104 cases. Turk J Cancer 1993;23:81-9.

17. Cavdar AO, Gozdasoglu S, Yavuz G, Babacan E, Unal E, Uluoglu O, Yucesan S, Magrath IT, Akar N. Burkitt's lymphoma between African and American types in Turkish children:clinical, viral (EBV) and molecular studies. Med Pediatr Oncol 1993;21:36-42. [CrossRef]

18. Alavi S, Arzanian MT, Abbasian MR, Ashena Z. Tumor lysis syndrome in children with non-Hodgkin's lymphoma. Pediatr Hematol Oncol 2006;23:65-70. [CrossRef]

19. Olgar S, Yetgin S, Cetin M, Aras T, Akhan O. Electrolyte abnormalities at diagnosis of acute lymphocytic leukemia may be a clue for renal damage in long-term period. J Pediatr Hematol Oncol 2005;27:202-6. [CrossRef]

20. Buyukpamukcu M, Varan A, Aydın B, Kale G, Akata D, Yalcin B, Akyuz C, Kutluk T. Renal involvement of non-
Hodgkin's lymphoma and its prognostic effects in childhood. Nephron Clin Pract 2005;100:86-91. [CrossRef]

21. Truong TH, Beyene J, Hitzler J, Abla O, Maloney AM, Weitzman S, Sung L. Features at presentation predict children with acute lymphoblastic leukemia at low risk for tumor lysis syndrome. Cancer 2007;110:1832-9. [CrossRef]

22. Pui CH, Jeha S, Irwin D, Camitta B.recombinant urate oxidase (rasburicase) in the prevention and treatment of malignancy-associated hyperuricemia in pediatric and adult patients: results of a compassionate-use trial. Leukemia 2001;15:1505-9. [CrossRef]

23. Bertrand Y, Mechinaud F, Brethon B, Mialou V, Auvrignon A, Nelken B, Notz-Carrére A. SFCE (Société Française de Lutte contre les Cancers et Leucémies de l'Enfant et de l'Adolescent) recommendations for the management of tumor lysis syndrome (TLS) with Rasburicase: An observational survey. J Pediatr Hematol Oncol 2008;30:267-71. [CrossRef]

24. Annemans L, Moeremans K, Lamotte M, Garcia Conde J, van den Berg H, Myint H, Pieters R, Uyttebroeck A. Pan-European multicentre economic evaluation of recombinant urate oxidase (rasburicase) in prevention and treatment of hyperuricaemia and tumor lysis syndrome in haematological cancer patients. Support Care Cancer 2003;11:249-57. 